Original Article

\title{
Cutaneous leishmaniasis-Awareness, knowledge and practices among general population in rural and urban areas in Malakand region, Pakistan
}

\author{
Leishmaniose cutânea - conscientização, conhecimentos e práticas entre a população \\ em geral nas áreas rurais e urbanas da região de Malakand, Paquistão
}

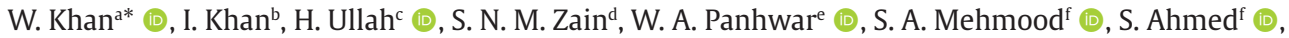

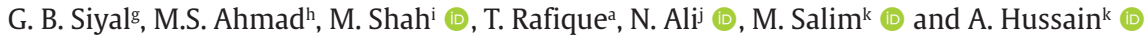 \\ aUniversity of Malakand, Laboratory of Parasitology, Department of Zoology, Lower Dir, Khyber Pakhtunkhwa, Pakistan \\ bSwat Medical College, Medical College, Saidu Group of Teaching Hospital, Medical Unit A, Saidu Sharif Swat, Khyber Pakhtunkhwa, Pakistan \\ 'University of Peshawar, Department of Zoology, Peshawar, Pakistan \\ dUniversity of Malaya, Institute of Biological Sciences, Faculty of Science, Kuala Lumpur, Malaysia \\ eShah Abdul Latif University Khairpur, Department of Zoology, Miris, Sindh, Pakistan \\ ${ }^{\mathrm{f}}$ Hazara University, Department of Zoology, Mansehra, Pakistan

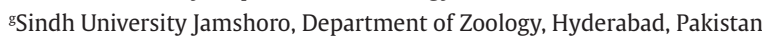 \\ hUniversity of Swabi, Department of Zoology, Swabi, KP, Pakistan \\ iUniversity of Swat, Centre for Animal Sciences \& Fisheries, Swat, Pakistan \\ jUniversity of Haripur · Department of Plant Breeding \& Genetics, Haripur, Pakistan \\ kUniversity of Haripur, Department of Forestry and Wildlife Management, Haripur, Pakistan
}

\begin{abstract}
Malakand region is an endemic area for cutaneous leishmaniasis (CL). However, there are limited number of studies of this disease in Pakistan. Therefore, a study was conducted to understand the level of awareness attitude and practice among the residents of Makaland towards CL and the disease vectors. This study adopted a cross-sectional approach with a total of 400 respondents ( $n=93$ rural and $n=307$ urban). Overall, the population in Malakand region (61.2\%) were well-informed in the role of sand fly in transmitting diseases, but most lack knowledge on the vector's behavior and almost a quarter (24.5\%) were unable to provide knowledge on proper control measures. Alarmingly, the practice and attitudes of the general population was not satisfactory as close to half $(49.8 \%)$ of the population did adopt any control method. This study calls for increase in awareness through health education campaign to reduce the risk of cutaneous leishmaniasis outbreaks in the future.
\end{abstract}

Keywords: oriental sore, local knowledge, leishmaniasis, sand flies, preventive measurement.

\begin{abstract}
Resumo
A região de Malakand é uma área endêmica para leishmaniose cutânea $(\mathrm{CL})$. No entanto, há um número limitado de estudos sobre esta doença no Paquistão. Portanto, foi realizado um estudo para entender o nível de atitude e prática de conscientização entre os residentes de Makaland em relação aos CL e os vetores da doença. Este estudo adotou uma abordagem transversal com um total de 400 entrevistados ( $n=93$ rural e $n=307$ urbano). No geral, a população da região de Malakand (61,2\%) estava bem informada sobre o papel da mosca na transmissão de doenças, mas a maioria não possui conhecimento sobre o comportamento do vetor e quase um quarto (24,5\%) foi incapaz de fornecer conhecimento sobre medidas de controle adequadas . De maneira alarmante, a prática e as atitudes da população em geral não foram satisfatórias, pois cerca da metade $(49,8 \%$ ) da população adotou algum método de controle. Este estudo apela ao aumento da conscientização por meio de campanhas de educação em saúde para reduzir o risco de surtos de leishmaniose cutânea no futuro.
\end{abstract}

Palavras-chave: ferida oriental, conhecimento local, leishmaniose, moscas da areia, medição preventiva.

\section{Introduction}

Cutaneous leishmaniasis (CL) is reported in more than 80 countries including Pakistan, America, Saudia Arabia, Syria, Iran and Afghanistan. World Health Organization reports the annual incidence of 1.5 million cases of $\mathrm{CL}$ per year (Sharma et al., 2003). An estimated 350 million people are at risk, including 12 million that are infected.

*e-mail: walikhan.pk@gmail.com

Received: May 25, 2020 - Accepted: July 27, 2020 
Pakistan records most numbers of cutaneous and visceral leishmaniosis globally with incidence up to $2.7 \%$ in the northwestern part of Pakistan. More than 4.6 cases/1000 persons/year have been reported over the last twenty years (Magill, 1995).

The high incidences of CL have been linked to deforestation, road construction or other human activity associated with sand fly habitat (Magill, 1995). Cutaneous Leishmaniasis have also become more prevalent throughout the world due to increase in international travel, immigration, cross-borders military exercises, and co-infection with HIV. Over the last two decades, the health problems related to CL has increased particularly from the endemic regions in Pakistan (Rahman and Bari, 2003).

The world's largest outbreak of cutaneous leishmaniasis occurred in Kabul (Afghanistan) which affected about 9\% of the population (Anbareen, 2014). However, historically, the emergence of $C L$ in the region began after an earthquake in Quetta in 1935, a town located in northern Balochistan near the Pakistan-Afghanistan border (Anbareen, 2014). Subsequently, more cases were detected after the Soviet invasion in Afghanistan, when approximately 3.5 million Afghan refugees migrated to Pakistan, through the west border of Khyber Pukhtunkhwa (Brooker et al., 2004) and settled in Jalala camp in Mardan; one of the largest camps which conceded this infection to local population. This disease is known by local people as "Da Kabalyano Bemari" (disease of Afghan people) while in Afghanistan it is known as 'Saldana' (Anbareen, 2014). Large movements of a number of internal displaced people (IDPs) is concerning as Malakand region is a part of Khyber Pakhtunkhwa Pakistan, a known area endemic for cutaneous leishmaniasis where health facilities are lacking. To date, only sporadic cases have been reported. The first outbreak in Pakistan was reported in Sindh in 1960 (Munir et al., 1989).

Therefore, this study is the first to determine the level of awareness and attitude of residents of Malakand region, Pakistan concerning $\mathrm{CL}$ in the region. The study aims at highlighting the concern to policymakers and to formulate strategies in disease control.

\section{Materials and Methods}

\subsection{Study area}

This study was conducted in the rural and urban areas of Malakand district, in northwestern part of Pakistan (Latitude: 34.5030413 longitude: 71.9045649 with $454.23 \mathrm{~m}$ elevation). The district and its surrounding areas has an average rainfall of $743 \mathrm{~mm}$, and temperature of $19.9^{\circ} \mathrm{C}$. The warm and humid climate provides a favorable habitat for breeding of sandflies.

\subsection{Ethical approval and informed consent}

The research was approved by the ethical review committee of the University of Malakand A consent letter was issued to the parents/guardians of pupils aged less than 18 years.

\subsection{Data collection}

The questionnaire was structured to gather sociodemographic information, knowledge related to sand flies and cutaneous leishmaniasis and finally attitude and practices towards the CL. Knowledge related to sand flies was measured through questions on the disease spread, breeding sites, biting time and control methods. Knowledge of leishmaniasis was assessed through questions related to symptoms and vector, peak incidence time, transmission and treatment for disease. However, attitudes and practices of respondents were evaluated through knowledge on severity of the disease, patient care, and control methods.

\subsection{Statistical analysis}

The data was analyzed descriptively using Graph Pad version 5 . The $\mathrm{p}$-values less than or equal to 0.05 were considered significant (at $95 \% \mathrm{CI}$ ).

\section{Results and Discussion}

The present study was able to gather information from 400 respondents (rural $n=93$ rural; urban $n=307$ urban) with almost equal representation of females (49\%) and males (51\%). Most respondents were above 18 years of age $(84.2 \%)$, while majority were literate (85.2\%). Number of households with less than 10 members was higher (73.2\%) (Table 1). Respondents were subdivided as rural and urban however, none of the characteristics were significantly different.

\subsection{Knowledge in relation to the vector and control measures}

Results of the current study as shown in Table 2 indicate that majority of the local population (61.2\%) were able to differentiate sandflies from other flies. Slightly more than half (53.5\%) understood that sandflies transmit cutaneous leishmaniasis. The finding differ from that of Akram et al. (2015), which revealed that only $1 / 5$ of respondents were able to differentiate sandflies from common house flies and mosquitoes and only a small proportion (9.2\%) knew that sandflies transmit leishmaniasis.

Regarding knowledge on breeding sites for sandflies, slightly more than a third of the respodents noted dirty environment as breeding sites for the vector. However, both the urban and rural population were unable to give accurate description of breeding sites and only listed moist habitat, and fresh water as some of the vector breeding sites. Akram et al., 2015 observed that majority of the respondents (59.6\%) lacked knowledge of sand fly breeding site and listed unhygienic environment as one of the breeding grounds, followed with moist places, fresh water and hospitals waste disposal sites. Khan et al.(2017) identified mud houses, cattle sheds and plants belonging to the Cucurbitaceae family as potential breeding and resting microhabitats for sand flies in Dir district in Pakistan.

Regarding knowledge of the biting time of sand flies, mixed responses were recorded between the rural and urban dwellers, with respect to dusk and dawn (20.4\%, $23.4 \%$ ), daytime (22.5\% and $15.9 \%$ ), night (29\% and $29.6 \%$ ), 
Table 1. Socio-demographic characteristics of respondents in Malakand region, Pakistan ( $n=400)$.

\begin{tabular}{|c|c|c|c|c|c|}
\hline & Rural & Urban & Total & \multirow{2}{*}{$(\%)$} & \multirow{2}{*}{$P$ value } \\
\hline & $(\mathrm{N}=93)$ & $(\mathrm{N}=307)$ & $(\mathrm{N}=400)$ & & \\
\hline \multicolumn{6}{|l|}{ Sex } \\
\hline Female & $59(63.4)$ & $137(44.6)$ & $196(49)$ & 49 & 0.0354 \\
\hline Male & $34(36.5)$ & $170(55.3)$ & $204(51)$ & 51 & \\
\hline \multicolumn{6}{|l|}{ Age } \\
\hline$<18$ years & $25(26.8)$ & $39(12.7)$ & $63(15.7)$ & 15.7 & 0.4553 \\
\hline$>18$ years & $68(73.1)$ & $268(87.2)$ & $337(84.2)$ & 84.2 & \\
\hline \multicolumn{6}{|l|}{ Education } \\
\hline Literate & $57(61.2)$ & $284(92.5)$ & $341(85.2)$ & 85.2 & 0.4996 \\
\hline Illiterate & $36(38.7)$ & $23(7.4)$ & $59(14.7)$ & 14.7 & \\
\hline \multicolumn{6}{|l|}{ Occupation } \\
\hline Teacher & $9(9.6)$ & $15(4.8)$ & $24(6)$ & 6 & 0.5336 \\
\hline Others & $84(90)$ & $292(95.1)$ & $376(94)$ & 94 & \\
\hline \multicolumn{6}{|c|}{ Number of household members } \\
\hline$<10$ & $59(63.4)$ & $234(76.2)$ & $293(73.2)$ & 73.2 & 0.3195 \\
\hline$>10$ & $34(36.5)$ & $73(23.7)$ & $107(26.7)$ & 26.7 & \\
\hline
\end{tabular}

Table 2. The level of Knowledge on vectors of cutaneous lishmaniasis among residents of Malakand region Pakistan $(\mathrm{n}=400)$.

\begin{tabular}{|c|c|c|c|c|}
\hline \multirow{2}{*}{ Characteristics } & Rural & Urban & \multirow{2}{*}{ P value } & \multirow{2}{*}{ 95\%CL } \\
\hline & $(\mathrm{N}=93)$ & $(\mathrm{N}=307)$ & & \\
\hline \multicolumn{5}{|c|}{ Can you differentiate sand flies from other flies? } \\
\hline Yes & 49(52.6) & 196(63.8) & 0.7268 & -216.7 to \\
\hline No & $44(47.3)$ & $111(36.1)$ & & 179.7 \\
\hline \multicolumn{5}{|l|}{ Do sandflies transmit the disease? } \\
\hline Yes & $45(48.3)$ & $169(63.8)$ & 0.0248 & -103.9 to \\
\hline I don't know & $48(51.6)$ & $138(44.9)$ & & -8.778 \\
\hline \multicolumn{5}{|c|}{ Do you know the breeding sites of sandflies? } \\
\hline Dirty environment & $29(31.1)$ & $109(35.5)$ & 0.0431 & -99.83 to \\
\hline Fresh water & $13(13.9)$ & $26(8.4)$ & & -2.175 \\
\hline Moist places & $27(29)$ & $68(22.1)$ & & \\
\hline I don't know & $24(25)$ & 104(33.8) & & \\
\hline \multicolumn{5}{|c|}{ Do you know biting time of sandflies? } \\
\hline Day time & $21(22.5)$ & $49(15.9)$ & 0.0012 & -82.90 to \\
\hline Night time & $27(29)$ & $91(29.6)$ & & -41.10 \\
\hline During dusk and dawn & $19(20.4)$ & $72(23.4)$ & & \\
\hline I don't know & $26(27.9)$ & $95(30.9)$ & & \\
\hline \multicolumn{5}{|c|}{ Do you know how to control sandflies? } \\
\hline Insecticide spray & $22(23.6)$ & $102(33.2)$ & 0.0126 & -76.37 to \\
\hline Insect repellent & $20(21.5)$ & $48(15.6)$ & & -12.43 \\
\hline Keeping area clean & $12(12.9)$ & $53(17.2)$ & & \\
\hline Install door and window mesh & $15(16.1)$ & $30(9.7)$ & & \\
\hline I don't know & $24(25.8)$ & $74(24.1)$ & & \\
\hline
\end{tabular}


while $27.9 \%$ and $30.9 \%$ respectively had no idea. Similarly, Akram et al., 2015 noted more than half (54.8\%) were unaware of the biting time of sandflies, followed by mixed responses (dusk and dawn (14\%), any time of the day (13.2\%), daytime (10\%) and midnight (8\%). These similar responses were also highlighted by Singh et al.(2006) in India.

With regards to control measures, only a small number of respondents were of the opinion that sand flies can be controlled by the use of insect screens on doors and windows. Others listed the use of insect repellents, insecticide sprays, hygienic conditions as several control measure, however almost a quarter (24.5\%) were unable to give any preventive methods.

Overall, the population in Malakand region were knowledgeable about sandflies however, they lack knowledge about the vector's behavior and proper control measures. Similarly, a study in India showed that majority of the people were aware of leishmaniasis and sand flies (Singh et al., 2006).
The findings of Iran Shiraz (Rakhshani et al., 2017) indicated that knowledge of participants in their study was below average. About half of the respondents implicated sandflies as vector of the disease in Afghanistan (Stewart and Brieger, 2009). The reason is that the disease is endemic to Afghanistan. On the other hand, shortage of knowledge was especially prominent in Isfahan regarding to sand fly identification and behavior, the ways of vector control and finally use of sand fly controlling methods such as use of insecticides and repellent-impregnated bed nets (Hejazi et al., 2013).

\subsection{Knowledge in relation to the disease}

In general, approximately half of respondents were aware of CL(Table 3). Similarly, only half of the respondents knew about the vector of the disease (rural: 52.6\%; urban 50.1\%:) while the rest were unaware or identified the wrong vector. Disease awareness were obtained primarily through

Table 3. Knowledge of Leishmaniasis among the population in Malakand region, Pakistan $(n=400)$.

\begin{tabular}{|c|c|c|c|c|}
\hline Characteristics & Rural (N=93) & Urban $(\mathrm{N}=307)$ & P value & $\mathbf{9 5 \% C l}$ \\
\hline \multicolumn{5}{|c|}{ Have you heard about leishmaniasis or oriental sore? } \\
\hline Yes & $49(52.6)$ & $159(51.7)$ & 0.0506 & -129.8 to 0.2112 \\
\hline Radio/television & $7(7.5)$ & $14(4.5)$ & & \\
\hline Print media & $18(19.3)$ & $63(20.5)$ & & \\
\hline Teacher/lecturer & $24(25.8)$ & $82(26.7)$ & & \\
\hline I don't know & $44(47.3)$ & $148(48.2)$ & & \\
\hline \multicolumn{5}{|c|}{ Do you know symptoms of cutaneous leishmaniasis? } \\
\hline Skin infection & $36(38.7)$ & $190(61.8)$ & 0.2216 & -10.52 to 37.02 \\
\hline Painful & $7(7.5)$ & $5(1.6)$ & & \\
\hline Very itchy & $8(8.6)$ & $6(1.9)$ & & \\
\hline I don't know & $42(45.1)$ & $106(34.5)$ & & \\
\hline \multicolumn{5}{|c|}{ Do you know the vector of the disease? } \\
\hline Housefly & $2(2.1)$ & $3(0.9)$ & 0.2368 & -153.1 to 46.13 \\
\hline Sand fly & $35(37.6)$ & $134(43.6)$ & & \\
\hline Mosquito & $7(7.5)$ & $16(5.2)$ & & \\
\hline I don't know & $49(52.6)$ & $154(50.1)$ & & \\
\hline \multicolumn{5}{|c|}{ Can leishmania be transmitted from human to human? } \\
\hline Yes & $59(63.4)$ & 215(70) & 0.2303 & -377.0 to 163.0 \\
\hline No & $34(36.5)$ & $92(29.9)$ & & \\
\hline \multicolumn{5}{|c|}{ When does the disease incidence peak? } \\
\hline Spring & 0 & 0 & 0.2996 & -131.8 to 46.20 \\
\hline Summer & $31(33.3)$ & $123(40)$ & & \\
\hline Winter & $3(3.2)$ & $2(0.6)$ & & \\
\hline Autumn & $2(2.1)$ & $6(1.9)$ & & \\
\hline I don't know & $57(61.2)$ & $176(57.3)$ & & \\
\hline \multicolumn{5}{|c|}{ Is leishmaniasis curable? } \\
\hline Yes & $60(64.5)$ & $21(50)$ & 0.8170 & -173.4 to 153.4 \\
\hline No & $33(35.4)$ & $92(29.9)$ & & \\
\hline
\end{tabular}


Table 4. Attitude and practices related to Lishmaniasis among residents of Malakand region $(n=400)$.

\begin{tabular}{|c|c|c|c|c|}
\hline Characteristics & Rural (N=93) & Urban $(\mathrm{N}=307)$ & P value & 95\%Cl \\
\hline \multicolumn{5}{|l|}{ Seriousness of the disease } \\
\hline $\begin{array}{l}\text { Leishmaniasis is more serious than } \\
\text { malaria }\end{array}$ & $64(68.8)$ & $205(66.7)$ & 0.1880 & -341.0 to 127.0 \\
\hline $\begin{array}{l}\text { Malaria is more serious than } \\
\text { leishmaniasis }\end{array}$ & $29(31.1)$ & $102(33.2)$ & & \\
\hline \multicolumn{5}{|l|}{ Patient care } \\
\hline Cleanliness & $37(39.7)$ & $191(62.2)$ & 0.1993 & -200.2 to 57.57 \\
\hline Use of bed net & $32(34.4)$ & $35(11.4)$ & & \\
\hline I don't know & $24(25.8)$ & $81(26.3)$ & & \\
\hline \multicolumn{5}{|c|}{ Preventive measures for cutaneous leishmaniasis (oriental sore) } \\
\hline Reduce outdoor activities & & & 0.1588 & -134.9 to 27.88 \\
\hline Use of bed net & $37(39.7)$ & $48(15.6)$ & & \\
\hline Insect repellent & $12(12.9)$ & $37(12)$ & & \\
\hline Health education & $20(21.5)$ & $47(15.3)$ & & \\
\hline I don't know & $24(25.8)$ & $175(57)$ & & \\
\hline
\end{tabular}

teachers/lecturers (rural: 28.5\%; urban 26.7\%) followed by print media (rural:19.3\%; urban: $20.5 \%$ ). Most of the respondents believed that this disease can be transmitted from human to human while, majority of the respondents had no knowledge when the disease incidence peaked and believed that this disease is curable disease.

This result showed moderate knowledge among respondents in relation to knowledge of the disease. In contrast, study conducted in Punjab was not showing satisfactory level of awareness by the respondents (Akram et al., 2015). While a study in India (Singh et al., 2006) showed a large proportion of the population were aware of this disease.

The results of the study showed that only half of the respondents were aware that sandflies is the vector of leishmania. The basic knowledge on leishmaniasis and sand flies is a matter of public health concern as this knowledge is the foundation for proper control measures and treatment (Khan et al., 2017). A cross sectional study of 300 households in Iran showed that knowledge of leishmaniasis and practices related to the disease were below average. However, the score for attitude was above average and concluded that knowledge and practices of people are pivotal step in the successful implementation of control strategies (Rakhshani et al., 2017). In Syria, insects were the most frequently mentioned as disease causing agents, suggesting insect bites as the cause of disease with nearly half of the respondents implicating sandflies, and approximately one-quarter implicated mosquitoes (Abazid et al., 2012). According to a cost-effective analyses study for the treatment of CL in Kabul, Afganistan, treatment may not be a viable option (Reithinger and Coleman, 2007) thus, educating the public of this disease is more important.

\subsection{Attitudes and practices related to cutaneous leishmaniasis}

More than $60 \%$ (rural: $68.8 \%$; urban $66.7 \%$ ) of the respondents noted that leishmaniasis is more serious than malaria (Table 4). When asked about patient care, most respondents prioritized cleanliness (57\%), followed by use of bed nets (26.3\%). Similar to a study in Punjab province (Akram et al., 2015), the use of bed nets, insect repellent, health education were some control measures adopted. However, majority of the respondents (49.8\%) did not adopt any control method. In Nepal, a study identified the use of bed nets as the strongest protective effect against CL (Bern et al., 2000). While, a study in Colombia demonstrated that the number of Lutzomyia sand flies caught with human bait was reduced by using untreated bed nets compared to no bed nets (Courtenay et al., 2007). Insecticide-treated bed nets are likely to have a stronger protective effect than that of untreated bed nets (Alexander and Maroli, 2003).

The overall result highlights the lack of preventive measures against the disease and vector. Current findings call for improvements in health education to improve attitude and practices related to leishmaniasis and sand flies among people of Malakand region Pakistan to reduce disease incidence.

\section{Acknowledgements}

The authors are thankful to the participants who voluntarily participated in the study. No funding was available for the conduction of this study.

\section{References}

ABAZID, N., JONES, C. and DAVIES, C.R., 2012. Knowledge, attitudes and practices about leishmaniasis among cutaneous leishmaniasis patients in Aleppo, Syrian Arab Republic. Eastern Mediterranean Health Journal, vol. 18, no. 1, pp. 7-14.

AKRAM, A., KHAN, H.A.A., QADIR, A. and SABIR, A.M., 2015. A Cross-sectional survey of knowledge, attitude and practices 
related to cutaneous leishmaniasis and sand flies in Punjab, Pakistan. PLoS One, vol. 10, no. 6, pp. e0130929. http://dx.doi. org/10.1371/journal.pone.0130929. PMid:26090870.

ALEXANDER, B. and MAROLI, M., 2003. Control of phlebotomine sandflies. Medical and Veterinary Entomology, vol. 17, no. 1, pp. 1-18. http://dx.doi.org/10.1046/j.1365-2915.2003.00420.x. PMid:12680919.

ANBAREEN, S.A., 2014. Community Involvement in Controlling Cutaneous Leishmaniasis in Ikrampur Village of District Mardan through Dissemination of Information among Schoolchildren. Journal of Applied Environmental and Biological Sciences, vol. 4, no. 8S, pp. 368-370.

BERN, C., JOSHI, A.B., JHA, S.N., DAS, M.L., HIGHTOWER, A., THAKUR, G.D. and BISTA, M.B., 2000. Factors associated with visceral leishmaniasis in Nepal: bed-net use is strongly protective. The American Journal of Tropical Medicine and Hygiene, vol. 63, no. 3-4, pp. 184-188. http://dx.doi.org/10.4269/ajtmh.2000.63.184. PMid:11388512.

BROOKER, S., MOHAMMED, N., ADIL, K., AGHA, S., REITHINGER, R., ROWLAND, M., ALI, I. and KOLACZINSKI, J.. 2004. Leishmaniasis in refugee and local Pakistani populations. Emerging Infectious Diseases, vol. 10, no. 9, pp. 1681-1684. http://dx.doi.org/10.3201/ eid1009.040179. PMid:15498178.

COURTENAY, O., GILLINGWATER, K., GOMES, P.A.F., GARCEZ, L.M. and DAVIES, C.R., 2007. Deltamethrin-impregnated bed nets reduce human landing rates of sand-fly vector Lutzomyia longipalpis in Amazon households. Medical and Veterinary Entomology, vol. 21, no. 2, pp. 168-176. http://dx.doi.org/10.1111/j.13652915.2007.00678.x. PMid:17550436.

HEJAZI, S.H., HAZAVEI, M.M., BIDABADI, L.S., SHADEMANI, A., SIADAT, A.H., ZOLFAGHARI-BAGH BADERANI, A., NILFOROUSHZADEH, M.A. and HOSSEINI, S.M., 2013. Evaluation of Knowledge, attitude and performance of the mothers of children affected by cutaneous Leishmaniasis. Infectious Diseases: Research and Treatment, vol. 3, pp. 1-6.

KHAN, K., WAHID, S., KHAN, N.H. and ALI, N., 2017. Potential resting and breeding sites of sand Flies (Diptera: Psychodidae) and their habitat characteristics in Leishmaniasis Foci of Dir Districts, Khyber Pakhtunkhwa, Pakistan. Journal of Medical Entomology, vol. 54, no. 5, pp. 1390-1396. http://dx.doi.org/10.1093/jme/ tjx098. PMid:28874012.

MAGILL, A.J., 1995. Epidemiology of the leishmaniasis. Dermatologic Clinics, vol. 13, no. 3, pp. 505-523. http://dx.doi.org/10.1016/ S0733-8635(18)30058-5. PMid:7554500.

MUNIR, M.A., RAB, M.A., IQBAL, J., GHAFOOR, A., KHAN, M.A. and BURNEY, M.I., 1989. A review of the status of leishmaniasis in Pakistan from 1960-1986. In: D.T. HART, ed. Leishmaniasis. Boston: Springer, pp. 47-56.

RAHMAN, S. and BARI, A., 2003. Laboratory profile in patients of cutaneous leishmaniasis from various regions of Pakistan. Journal of the College of Physicians and Surgeons--Pakistan, vol. 13, no. 6, pp. 313-316. PMid:12814526.

RAKHSHANI, T., KASHFI, M., EBRAHIMI, M.R., TARAVATMANESH, S. and RASHEKI, M., 2017. Knowledge, attitude and practice of the households about prevention of cutaneous leishmaniasis, Iran, Shiraz at 2016. Journal of Human Environment and Health Promotion, vol. 2, no. 3, pp. 186-192. http://dx.doi.org/10.29252/ jhehp.2.3.186.

REITHINGER, R. and COLEMAN, P.G., 2007. Treating cutaneous leishmaniasis patients in Kabul, Afghanistan: cost-effectiveness of an operational program in a complex emergency setting. BMC Infectious Diseases, vol. 7, no. 1, pp. 3. http://dx.doi. org/10.1186/1471-2334-7-3. PMid:17263879.

SHARMA, R.C., MAHAJAN, V.K., SHARMA, N.L. and SHARMA, A., 2003. A new focus of cutaneous leishmaniasis in Himachal Pradesh (India). Indian Journal of Dermatology, Venereology and Leprology, vol. 69, no. 2, pp. 170-172. PMid:17642870.

SINGH, S.P., REDDY, D.C., MISHRA, R.N. and SUNDAR, S., 2006. Knowledge, attitude, and practices related to Kala-azar In a rural area of Bihar state, India. The American Journal of Ttropical medicine and Hygiene, vol. 75, no. 3, pp. 505-508. http://dx.doi. org/10.4269/ajtmh.2006.75.505. PMid:16968930.

STEWART, C.C. and BRIEGER, W.R., 2009. Community views on cutaneous leishmaniasis in Istalif, Afghanistan: implications for treatment and prevention. International Quarterly of Community Health Education, vol. 29, no. 2, pp. 123-142. http://dx.doi. org/10.2190/IQ.29.2.c. PMid:19546088. 